\title{
Blockchain Technology into Gamification on Education
}

\author{
Qurotul Aini ${ }^{1}$, Untung Rahardja ${ }^{2}$, Alfiah Khoirunisa ${ }^{* 3}$ \\ ${ }^{1,2}$ Program Studi Sistem Informasi Universitas Raharja, Indonesia \\ ${ }^{3}$ Magister Teknik Informatika Universitas Raharja, Indonesia \\ e-mail: ${ }^{1}$ aini@ raharja.info, ${ }^{2}$ untung@ raharja.info, *3alfiah@ raharja.info
}

\begin{abstract}
Abstrak
Seperti kita ketahui, Indonesia sudah mulai memasuki era revolusi 4.0 yang pada era itu banyak terjadi perubahan di segala bidang termasuk kehadiran teknologi blockchain yang mulai diminati. Termasuk di bidang pendidikan, perubahan yang terjadi di dunia pendidikan saat ini begitu signifikan dengan dimulainya ditinggalkannya metode pengajaran yang masih menggunakan metode konvensional. Melacak tugas berdasarkan buku, komunikasi tatap muka, yang tentu saja akan menyebabkan banyak kerugian dalam periode waktu tertentu, karena banyak tugas yang telah lama terkubur menjadi sulit ditemukan ketika dibutuhkan, dan kemungkinan manipulasi tugas masih Bagus. Metode pembelajaran dianggap sebagai cara yang membosankan dan tidak aman, di mana siswa tidak dapat mengeksplorasi pembelajaran karena file yang dikumpulkan masih dapat dimanipulasi oleh pihak lain. Maka mulai sekarang penerapan metode pembelajaran diubah dengan konsep gamification yang mengandalkan teknologi blockchain. Metode pembelajaran gamifikasi diciptakan untuk mengimbangi saat-saat ketika siswa lebih suka bermain game daripada belajar, oleh karena itu metode gamifikasi dapat diterapkan untuk manajemen pendidikan di pendidikan tinggi.
\end{abstract}

Kata kunci-Revolution 4.0, Education, Gamification, Blockchain Technology

\begin{abstract}
As we know, Indonesia has begun to enter the era of revolution 4.0 which in that era there were many changes in all fields including the presence of blockchain technology which began to be in demand. Including in the field of education, the changes that occur in the world of education today are so significant with the commencement of the abandonment of teaching methods that still use conventional methods. Keep track of tasks by book, face to face communication, which of course will cause many losses in a certain period of time, as many tasks that have long been buried become difficult to find when needed, and the possibility of manipulation of tasks is still great. The learning method is considered as a boring and insecure way, where students cannot explore learning because the collected files can still be manipulated by other parties. So from now on the application of learning methods is changed by the concept of gamification which relies on blockchain technology. The gamification learning method was created to compensate for the times when students preferred to play games rather than learning, therefore the gamification method could be applied to management education in higher education.
\end{abstract}

Keywords-Revolution 4.0, Education, Gamification, Blockchain Technology 


\section{INTRODUCTION}

Learning methods that are currently running at several universities in Indonesia still use conventional methods in the teaching and learning process using paper as a media for the assignments given by the lecturer, discussing in class directly, collecting assignments by giving assignments to lecturers, continuing continuously every day. Of course, using such methods in the era of evolution 4.0 or the disturbing era at this time will be so saturated that students will become lazy and do not want to explore the learning process. Thus students will become more advanced but will be increasingly left behind in the learning process. Educational institutions or more precisely universities must see the impact that makes the weight of students when graduating will have stock in the world of work [1].
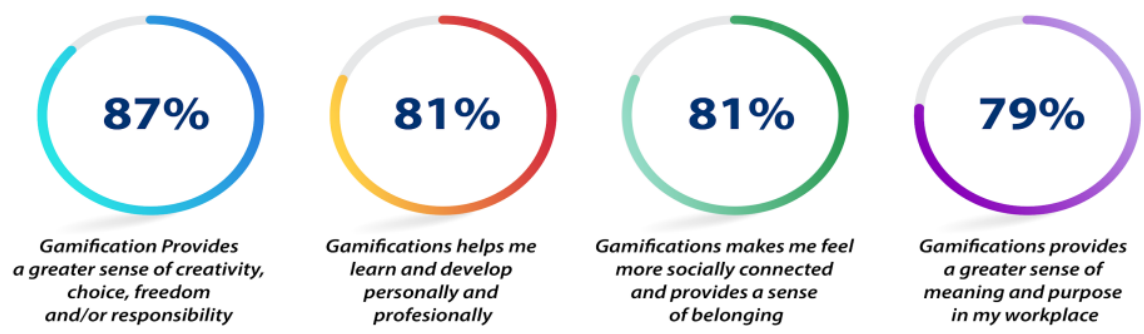

Figure 1. percentage of gamification impact surveys on students in Indonesia 2018 source: TalentLMS Gamification Survey

Currently, the application of a monotonous learning method makes students more easily stressed and saturated, so that not many students choose to play the game as a means to vent the saturation and stress felt. Because it can be proven when someone is playing a game, it can improve the feelings of students. Taking survey data from 120 students in 2018, from the percentage generated by the data shows that gamification has a very big effect on the progress of learning desires for students. Interest in student learning will certainly increase, making a sense of competition in learning to always want to know and be responsible for the task is getting higher. With that matter, some universities in Indonesia are aggressively looking for learning methods which are not boring but also make students also active and enthusiastic in following the learning process. Then a learning method is created that adapts from the elements contained in a game which is the method of gamification. Gamification in education management is a new learning method by adapting from characteristic elements in the game which can increase student motivation in the learning process. Experimentally, the gamification strategy has been confirmed to be successful in increasing the enthusiasm of the assessment students used to survey client behavior and observations about the use of iLearning [2].

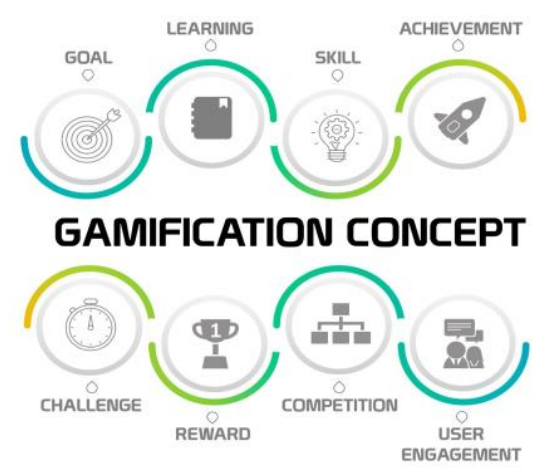

Figure 2. Gamification concept 
Gamification concept is an act of layering into features like game to platform, it is a powerful tool integrated with blockchain. We can make the concept of learning more fun processing us using treasure hunting or mission-based learning for students. Student points that can be accessed Special points that can be awarded. But how will this point be different? Each point can be distinguished and also distinguished, this time the point used can be called a NonFungible Token or NFT. NFT can be used as a method for recording ownership assets that cannot be shared and are very unique. The NFT can then be used to measure the learning experience because there will be competition between students and students to collect these tokens and complete this level, which can make the learning process more interesting and interesting. Gamification at a more basic stage can facilitate changes in the back, which can increase the number of students, challenge, engage, facilitate and teach them. So that students who feel bored with learning methods that have been applied previously can increase student learning spirit with game features applied in gamification learning methods such as, reward and interactive quizzes will add to the spirit of students and motivated to improve the exploration of the learning process that will increase student productivity of course. Educational institutions or universities also benefit from the growing process of learning that previously feels monotonous and will produce graduates who have extensive knowledge and weight as a stock in the world of work later. The philosopher Wittgenstein defines a game as "a range of disparate human activities that bear to one another only what one might call family resemblances" cited by Erenli [3]. According to Takashi [4], in a study conducted by (Sitaresmi Wahyu Handani [5], Gamification is a process aimed at changing non-game context (eg learning, teaching, marketing, etc.) to become much more interesting by integrating game thinking, game design, and game mechanics. According to research conducted by Acun Kardianawati, gamification is the application and use of game design elements into the context of non-game [6].

While research led by Endra Murti Sagoro, suggests gamification is a game based dynamic application in order to educate [7]. Gamification has been defined as a process of enhancing services with (motivational) affordances in order to invoke gameful experiences and further behavioral outcomes [8]. Then in the opinion expressed by Supriyanto [9] Gamification is an approach to the application of components and mechanisms of game or game in a system that is not game-based. From some understanding above about gamification, the writer can conclude that gamification is a method that uses component elements in a game which applied to a system which previously is non-game-context. Digital gaming is now pursued by a majority of the first world population. The age range of gamers gets younger every year while veteran gamers continue to play well beyond childhood, [10].

\subsection{Problem Analysis}

\section{METHODS}

Currently, the existence of the Internet makes less interest in student learning which makes them rarely do the tasks assigned by lecturers. After the rapid development of technology plus the internet, currently, some games make students more likely to be interested in the gadgets that are owned without concern for the ongoing learning activities. This is proven with the current teaching-learning activities only a few students who pay attention to the lecturers explain the material in the classroom and not a few students who are more interested in the gadget, so when the lecturer gives the task not a few of the students who missed in receiving information. It is according to the sense of saturation, because the learning process is still conventional, ie by entering the class of lecturers explain and give the task and then collect these tasks make the learning atmosphere feel monotonous or boring. There is research that explains there is a complementary relationship between learning, just as a lifetime of learning requires the use of writing skills, this also becomes one of the innovations of teaching staff creating gamification to present an atmosphere of fun learning but students still feel safe with assignments that can be manipulated without being manipulated by others [13]. Based on the 
percentage announced in Figure 1, the writer uses the data to draw a sample from a learning system that uses the gamification method and is embedded with a blockchain in it.

This sample data collection uses the Slovin formula. As Follows:

$$
n=\frac{\mathrm{N}}{\left(1+\mathrm{N} \cdot \mathrm{e}^{2}\right)}
$$

The number of samples if you follow the Slovin formula of the total population $(\mathrm{N}=250$ people) will produce a minimum sample of 74 people. with the following student sample:

$$
\begin{aligned}
& n=\frac{\mathrm{N}}{\left(1+\mathrm{N} \cdot \mathrm{e}^{2}\right)} \\
& n=\frac{250}{\left(1+250 \cdot(0,1)^{2}\right)} \\
& n=\frac{250}{(1+2,5)} \\
& n=\frac{250}{(3,5)} \\
& n=\mathbf{7 1 , 4 2 \% ( r o u n d e d ~ u p ~ t o ~} 72 \text { students) }
\end{aligned}
$$

The problem has been seen by Raharja University so as to create innovative learning in iLearning using iDu (iLearning Education), iMe (iLearning Media) and Rinfo in the learning method used. However, using the method is still considered not able to minimize the level of student interest is low due to the ongoing process of face-to-face learning when the lectures take place that can be considered less motivating students. According to a study conducted by Untung Rahardja, Khanna Tiara, and Ray Indra Taufik Wijaya, 2014, Rinfo is an official email used by Raharja Higher Education as a communication medium as well as a tool in the learning process that allows to send and receive an email from outside[14]. Meanwhile, according to a study conducted by Ary Budi Warsito, 2014. Rinfo is a Gmail service using google platform that is provided exclusively by Higher Education Raharja for Personal Raharja [15]. Then according to Untung Rahardja, Indri Handayani, and Rizki Afri Liani Firmansyah, 2016, Rinfo is a medium of communication as well as a supporting tool in the learning process in Higher Education Raharja. From some understanding of Rinfo above the authors conclude that Rinfo is an email service using the google platform that is provided exclusively by Higher Education Raharja for Personal Raharja [16].

According to a study conducted by Untung Rahardja, Muhammad Yusup and Qurotul Aini, $2014 \mathrm{iDu}$ or iLearning Education is an online learning medium to support traditional learning. iDu (iLearning Education) is one of the Ten Pillars iLearning utilizing ICT developed by Raharja College Online using a Cloud-hosted Learning Management System (LMS) without

IJCCS Vol. 14, No. 2, April 2020 : $147-158$ 
the need to install or download to facilitate the campus and college students in running the lecture [17] . According to Untung Rahardja, Sudaryono and Irwan Nurdin, 2014 in his study mention iMe (iLearning Media) is an official portal blogging dedicated to Personal Raharja, and each Personal Raharja will get a subdomain as a documentary media of all forms of Tridharma activity [18]. These problems can be used as a solution on how to add interest in student learning by combining several elements above. One of them is by applying gamification on the learning method of iLearning. Thus the interest of student learning can grow slowly.

\subsection{Research Method}

This research is using a qualitative approach by giving deep meaning to facts or existing data. The approach is used because in this study aims to describe or explain the data and facts of existing conditions, and to analyze what things should be done to achieve the desired condition in the future [19]. The method used in this research is a descriptive research method which is a research method that explains an object in accordance with existing conditions without changing it. In this study, the author will explain the effectiveness of learning methods with gamification on educational management in industrial era 4.0 today. A simple description is expected with the existence of this research can be developed and applied for the management system in higher education in Indonesia today can adapt to the current industrial era 4.0 and no less competitiveness with other fields [20]. In this study, the researchers set the place of research in Higher Education Raharja. The object of this study is the method of learning that is being used today to support industry era 4.0. The entire information the researchers obtained in this study was collected from several sources, namely human, system running and its application [21]. Other studies explain the effectiveness of learning in terms of teaching staff, have a great influence in Loyalty to the Curriculum, Teacher Dependence and Encourage students to think of creating interesting ways of learning that have important importance for the achievement of a learning goal. In selecting and determining the source of the data for this study, the writer used a purposive sampling procedure [22]. The procedure is taken and the sampling technique is based on the idea that sampling in qualitative research is the researcher's choice of what aspects of the event occur and who the research focuses on a particular situation, and therefore the continuous research in accordance with the approach used. So the instrument that researchers use to collect data is the researcher himself as a key instrument or main research tool is quite important by using some data collection techniques that are, interviews, observation, and literature study [23].

The process of data analysis conducted by researchers through the following stages: 1) make corrections to the data obtained when making observations. 2) make groups of data so that it is easy for drawing the conclusions later [24]. 3) give code to the existing data in order to make it easier to identify it. Data analysis is done as follows, namely data reduction, display data, and inference and verification. In every research course, there is a goal to be achieved. The purpose of this study is to see the effect of the application of gamification method in education management to improve the activity and motivate students' learning interest [25]. Because the conventional learning method is still not effective to increase interest in learning and activeness of a student in the learning process which makes the need for alternative methods to follow the development of the current disruptive era.

\section{RESULTS AND DISCUSSION}

In the issues that have been raised above, how to increase student motivation in the learning process. Because the primary purpose of higher education is to supplement or develop previously acquired knowledge and to develop areas of student interest. However, due to the decreasing interest and motivation of student learning, the primary purpose of higher education is slowly disappearing. Therefore, the elements of gamification or game elements applied to the lecture system in Higher Education Raharja, where the additional element with the aim of adding interest in learning as well as the spirit of students in lectures and doing the task. Games 
typically allow players to restart or play again, making mistakes recoverable. This freedom to fail will enable students to experiment without fear and increases student engagement [26]. Finally, the indicator that must be measured can be made a reference point to make instruments that are asked questions that need to be answered by respondents. Each answer can be agreed with words or forms supported by the following words:

\begin{tabular}{|l|c|}
\hline Very Satisfied / Very Important / Very Right & 5 \\
\hline Satisfied / Important / Correct & 4 \\
\hline Quite Satisfied / Quite Important / Quite Right & 3 \\
\hline Not Satisfied / Less Important / Wrong & 2 \\
\hline Dissatisfied / Unimportant / Very Wrong & 1 \\
\hline
\end{tabular}

Table 1. Questionnaire rating scale

In table 1 the data needed to assess the questionnaire is explained, data needed in this study will be taken through a questionnaire given to selected respondents. One supporting factor is the system gamification elements are made precisely as with the game that is developing to date, which is a reward that is very useful for students [27]. If you want to add value or close the value of empty or less on the task, students can use the point of the reward so that the task can be completed maximally and adequately. Also, lecturers can also see students who are very enthusiastic to follow the courses that are powerful with the gamification reward rating system, where on the top is the student who has the most points.

The giving point also has a rule which is, the point given must go through the requirements provided by the lecturer of the course in the pot. Each lecturer has its criteria for giving rewards to its students and is different. At university Raharja there are media in applying its gamification element, among which is iDu (iLearning Education). iMe (iLearning Media), and Rinfo (Raharja Info).

\section{Rinfo}

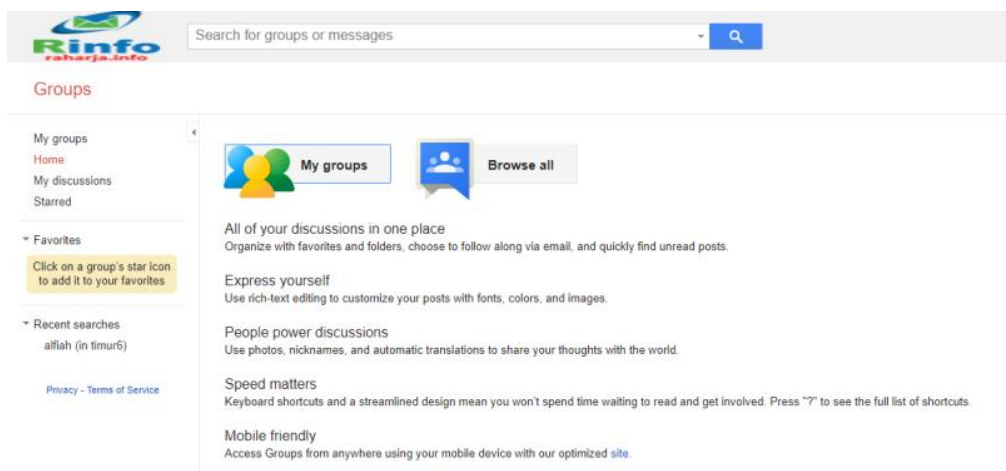

Figure 3. Rinfo groups

The picture above is the view of Rinfo groups, which can be used as a means of communication between lecturers and students. There are more than one Rinfo groups from each Rinfo account [28] . 


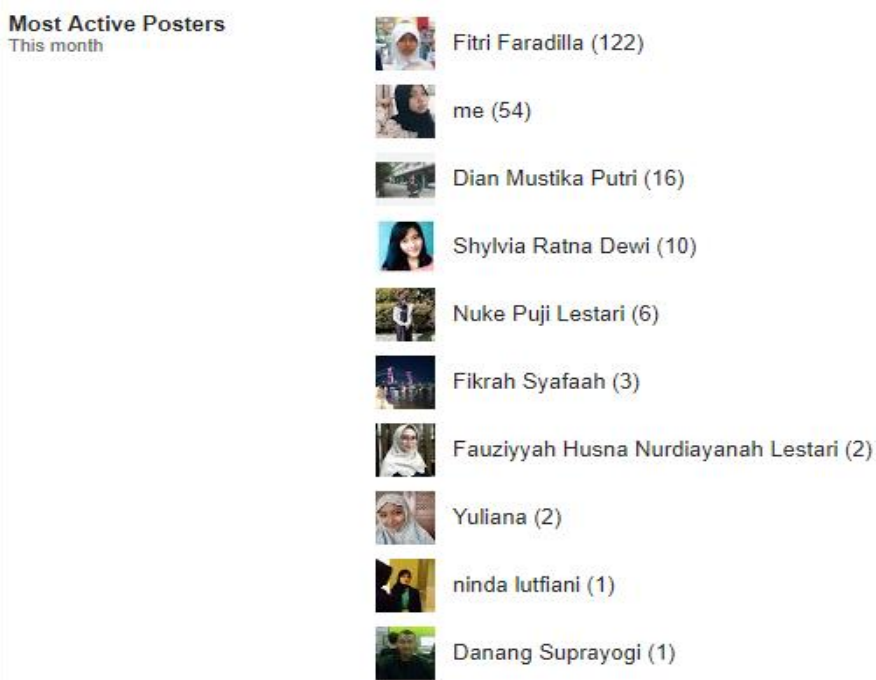

Figure 4. Student activeness view on Rinfo groups

Implementation of gamification in the Rinfo group, we can show the activities in the Rinfo group, the picture above is ten, or we can name the top 10 (ten) active students in each group. This ranking is obtained from the activeness of students sharing and communicating on the mailing list, students usually share tasks that have been done as a form of report for the guidance lecturer. It certainly can motivate students to do activities in the Rinfo group.

\section{2. iDu (iLearning Education)}

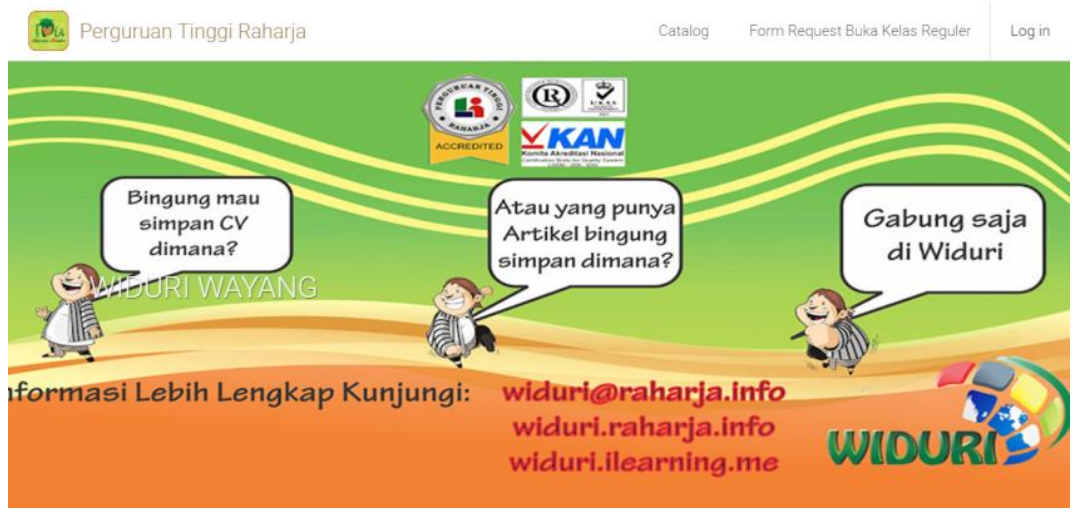

Figure 5. Login iDu (iLearning Education)

The image above is an iDu (iLearning Education) home page view to login. Users can log in using a username and password or can log in using SSO (Single Sign-On) by utilizing google apps button integrated with Rinfo email.

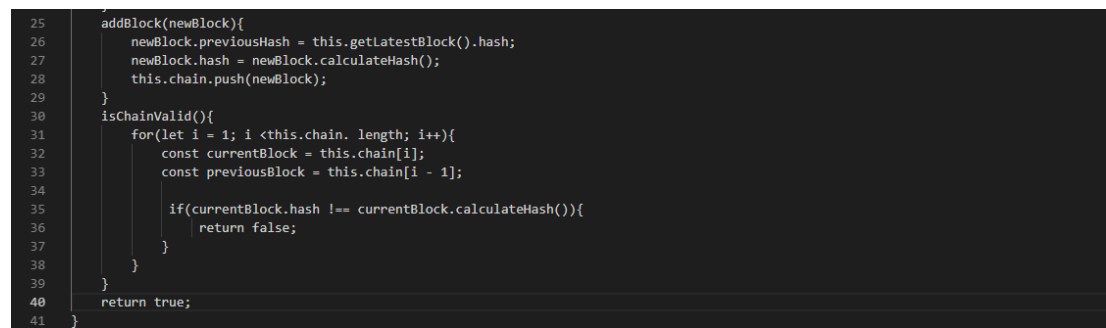

Figure 6. Blockchain Script on Gamifikasi Board 
Here is a small blockchain script that is used to display gamification boards on the initial display. There is a ranking or ranking of students who are active in the learning process, the ranking will be updated automatically and cannot be changed or deleted by the admin though.

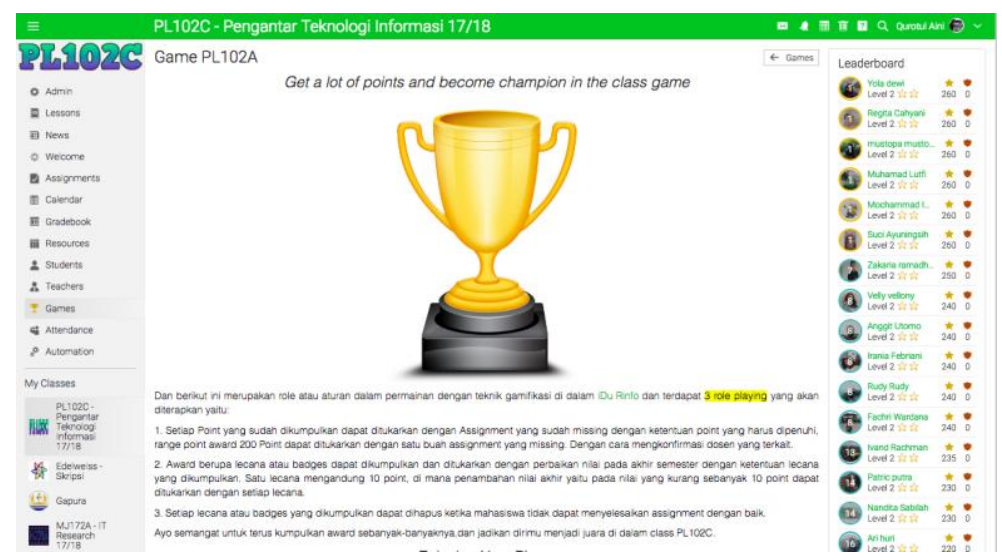

Figure 7. Gamification on iDu (iLearning Education)

The picture above is a gamification display that is on iDu (iLearning Education) along with rules and how to play it.

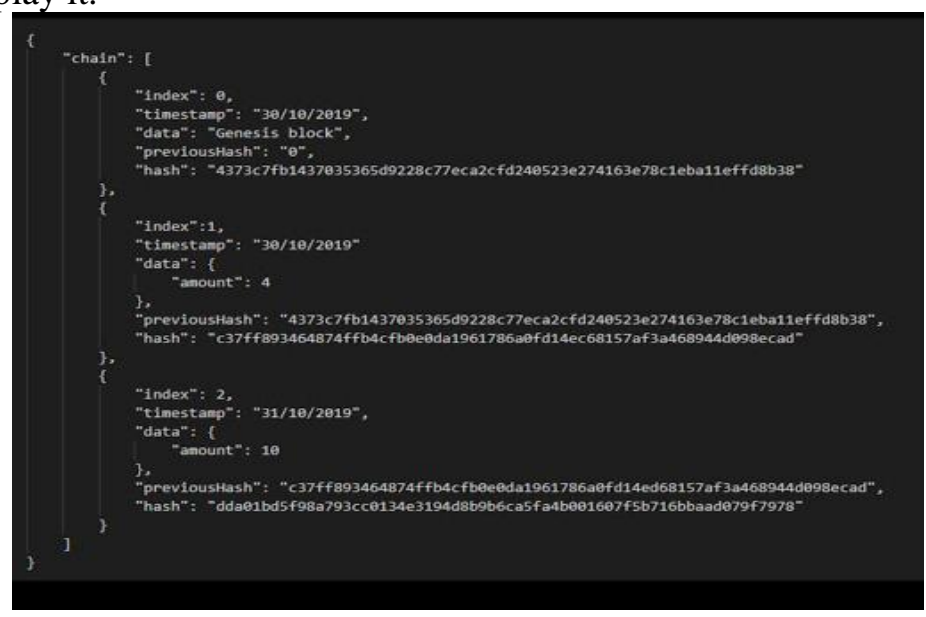

Figure 8. Gamification on iDu (iLearning Education)

The description script on the Gamification board, in this section explains what conditions students can do to get points and ranks.

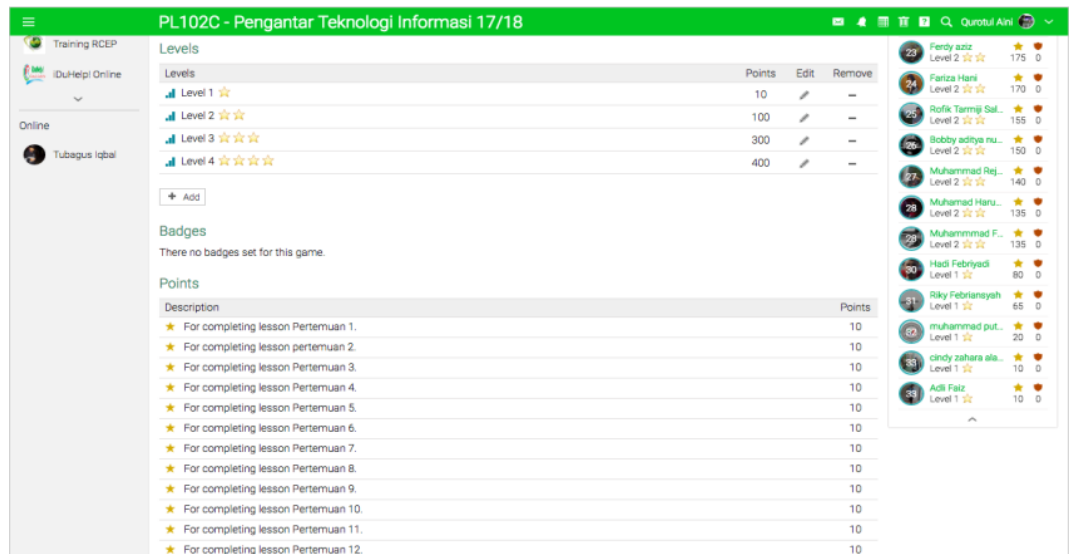

Figure 9. View directives and gamification levels on iDu (iLearning Education)

IJCCS Vol. 14, No. 2, April 2020 : $147-158$ 
The display on the picture above is the level of gamification level display on iDu (iLearning Education) along with the points obtained if successful through these.

\section{3. iMe (iLearning Media)}

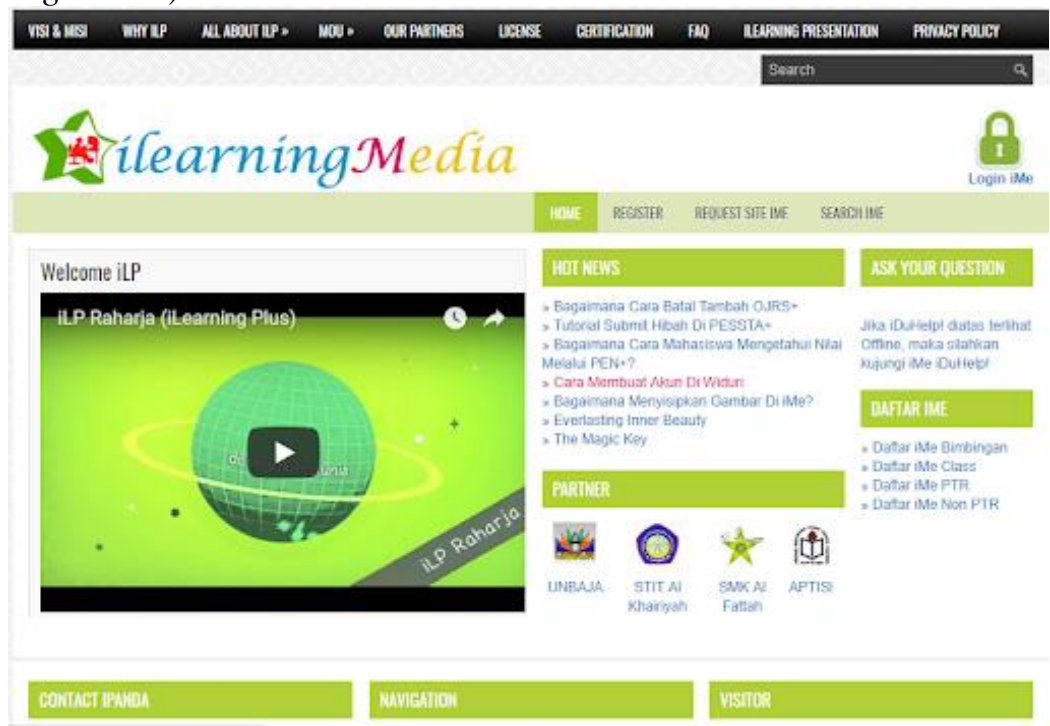

Figure 10. Login iMe (iLearning Media)

After gamification on Rinfo and iDu (iLearning Education), this time iMe (iLearning Media) will be discussed. The image above is a view of the login on iMe (iLearning Media) on iMe gamification or iLearning Media can be used as a good documentation media to capture SC (Special Contribution) obtained by students and enshrined in the window of each classroom.

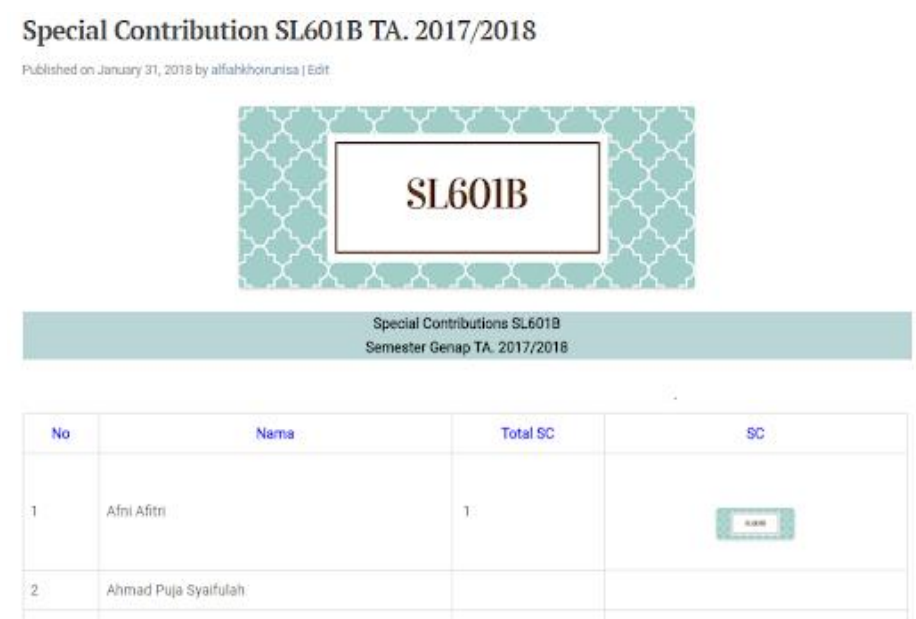

Figure 11. Gamification on iMe (iLearning Media)

The picture above is an example of an SC (Special Contribution) storefront given by faculty to its students. According to Gabe Zichermann, cited by (Giang, 2013), the use of game mechanics improves the abilities to learn new skills by $40 \%$. Game approaches lead to a higher level of commitment and motivation of users to activities and processes in which they are involved. 


\section{CONCLUSIONS}

With the application of gamification learning system using learning media iLearning that exist in Higher Education Raharja like Rinfo, iDu (iLearning Education), and iMe (iLearning Media), then the writer can conclude as follows:

Based on the results of testing with sample data collection on students who have done to a system that adopts the concept of gamification with blockchain integration, it is evident that there are $71 \%$ of students who say they really like and have a positive impact on student character.

The existence of a gamification system on learning method iLearning proved the learning process can be more interactive and more efficient, lecturers can also see which students who are active in the class.

The application of the gamification system makes students become more enthusiastic and motivated both in learning and to do the tasks that are given.

The learning method becomes more fun with the application of this system, but not forgetting the existing lecture material. Thus, there is a balance between teaching and learning and playing in learning.

Make students more active in the classroom by following the learning process, And Along with the increasing interest of students in the learning process, the significant development can be seen from the rise of student achievement index.

In a study, of course, has a limitation of research and what can be done in the future if the current research is running smoothly. So the weakness of this study is to assess how effective the application of gamification methods in educational management at Higher Education Raharja as an initial step to prepare themselves as educational institutions that contribute to fighting in the disruptive era that has grown. In the future, this research will try to apply the Gamification method not only in Higher Education but also on all campuses that exist in Indonesia.

\section{REFERENCES}

[1] Rahardja, U., \& Harahap, E. P. (2019, July). Implementation Of Information Planning and Strategies Industrial Technology 4.0 to Improve Business Intelligence Performance on Official Site APTISI. In Journal of Physics: Conference Series (Vol. 1179, No. 1, p. 012111). IOP Publishing.

[2] Binarsatya, B. A., \& Sani, N. A. (2018). Rancang Bangun Aplikasi Game Avatar dengan Menerapkan Gamifikasi untuk Meningkatkan Minat Pengunjung Objek-Objek Bersejarah di Surabaya. Jurnal Teknik ITS, 7(1), 110-112.

[3] Deveci, T. (2018). Writing for and Because of Lifelong Learning. European Journal of Educational Research, 8(1), 1-7.

[4] Dilekli, Y., \& Tezci, E. (2019). Adaptation of teachers' teaching thinking practices scale into english.

[5] Farozi, M. (2016). Rancang Bangun Website Gamifikasi sebagai Strategi Pembelajaran dan Evaluasi Hasil Belajar Mahasiswa. Semnasteknomedia Online, 4(1), 4-2. 
[6] Hamari, J., Koivisto, J., \& Sarsa, H. (2014, January). Does Gamification Work?-A Literature Review of Empirical Studies on Gamification. In HICSS (Vol. 14, No. 2014, pp. 3025-3034).

[7] Handani, S. W., Suyanto, M., \& Sofyan, A. F. (2016). Penerapan konsep gamifikasi pada e-learning untuk pembelajaran animasi 3 dimensi. Telematika, 9(1).

[8] Handayani, I. (2015). Pemanfaatan Sistem Ime (Ilearning Media) Dan Rinfo (Raharja. Info) Dalam Penerapan Sistem E-journal Di Ccit Journal Pada Perguruan Tinggi Raharja.

[9] Kristiadi, D., \& Mustofa, K. (2017). Platform Gamifikasi untuk Perkuliahan. IJCCS (Indonesian Journal of Computing and Cybernetics Systems), 11(2), 131-142.

[10] Haq, F. A. S. N., \& Nuryuliani, N. Digitalization On Students Scoring System of SMPN 18 Bekasi. IJCCS (Indonesian Journal of Computing and Cybernetics Systems), 13(3), 283-292

[11] Pesare, E., Roselli, T., Corriero, N., \& Rossano, V. (2016). Game-based learning and gamification to promote engagement and motivation in medical learning contexts. Smart Learning Environments, 3(1), 5.

[12] Rahardja, U. (2009, May). Artificial informatics. In 2009 4th IEEE Conference on Industrial Electronics and Applications (pp. 3064-3067). IEEE.

[13] Rahardja, U., \& Harahap, E. P. (2019, July). Implementation Of Information Planning and Strategies Industrial Technology 4.0 to Improve Business Intelligence Performance on Official Site APTISI. In Journal of Physics: Conference Series (Vol. 1179, No. 1, p. 012111). IOP Publishing.

[14] Rahardja, U., \& Nurdin, I. (2014). Implementasi iMe (iLearning Media) Dalam Mendukung Sistem Pembelajaran iLearning Pada Perguruan Tinggi. CCIT Journal, 8(1), 167-182.

[15] Rahardja, U., Aini, Q., \& Khoirunisa, A. (2017). Implementasi Business Intelligence Menggunakan Highchart pada Sistem Penilaian Absensi berbasis YII Framework. CSRID (Computer Science Research and Its Development Journal), 9(2), 115-124.

[16] Rahardja, U., Handayani, I., \& Firmansyah, R. A. L. (2016). Penerapan SPB Online Menggunakan Rinfo Transformation Pada Bagian Pengadaan Perguruan Tinggi. CogITo Smart Journal, 2(1), 69-81.

[17] Rahardja, U., Handayani, I., \& Ningrum, A. A. (2018). Pemanfaatan Sistem iMe Berbasis WordPress sebagai Official Site RCEP pada Perguruan Tinggi. Creative Information Technology Journal, 4(3), 207-219.

[18] Rahardja, U., Harahap, E. P., \& Anjani, D. (2018). Pemanfaatan Rinfogroup Sebagai Media Diskusi Dan Penilaian Keaktifan Mahasiswa. Sisfotenika, 8(1), 81-92.

[19] Rahardja, U., Hariguna, T., \& Aini, Q. (2019). Understanding the Impact of Determinants in Game Learning Acceptance: An Empirical Study. International Journal of Education and Practice, 7(3), 136-145. 
[20] Rahardja, U., Moein, A., \& Lutfiani, N. (2018). Leadership, Competency, Working Motivation and Performance of High Private Education Lecturer with Institution Accreditation B: Area Kopertis IV Banten Province. Man India, 97(24), 179-192.

[21] Rahardja, U., Tiara, K., \& Wijaya, R. I. T. (2014). Penerapan Rinfo Sebagai Media Pendukung Untuk Proses Pembelajaran Pada Perguruan Tinggi Raharja. CCIT Journal, $8(1), 101-115$.

[22] Rahardja, U., Yusup, M., \& Aini, Q. (2014). Aplikasi Campus Learning System iOU (integrated Online Ujian) Dalam Mendukung Kegiatan iLearning Education (iDu) Pada Perguruan Tinggi. CCIT Journal, 7(3), 368-383.

[23] Sagoro, E. M. (2016). Keefektifan Pembelajaran Kooperatif Berbasis Gamifikasi Akuntansi Pada Mahasiswa Non-Akuntansi. Jurnal Pendidikan Akuntansi Indonesia, 14(2).

[24] Sambung, D., Sihkabuden, S., \& Ulfa, S. (2018). Pengembangan Mobile Learning Berbasis Gamifikasi Untuk Penguasaan Kosakata Bahasa Jepang Kelas X Sman 1 Garum. JINOTEP (Jurnal Inovasi dan Teknologi Pembelajaran) Kajian dan Riset dalam Teknologi Pembelajaran, 3(2), 121-129.

[25] Sunarya, P. A., Rahardja, U., Aini, Q., \& Khoirunisa, A. (2019). Implementasi Gamifikasi Sebagai Manajemen Pendidikan Untuk Motivasi Pembelajaran. EDUTECH, 18(1), 67-79.

[26] Supriyanto, S. (2017). Perancangan Penerapan Gamifikasi pada Media Informasi Ekowisata. In Seminar Nasional Aplikasi Teknologi Informasi 2017. Islamic University of Indonesia. 